\title{
80-lecie urodzin prof. zw. dr. hab. dr. h.c. Tadeusza Wladysława Hermanna
}

\author{
Franciszek Główka \\ Katedra i Zakład Farmacji Fizycznej i Farmakokinetyki, \\ Uniwersytet Medyczny im. Karola Marcinkowskiego \\ w Poznaniu, ul. Święcickiego 6, 60-781 Poznań
}

Adres do korespondencji: glowka@ump.edu.pl

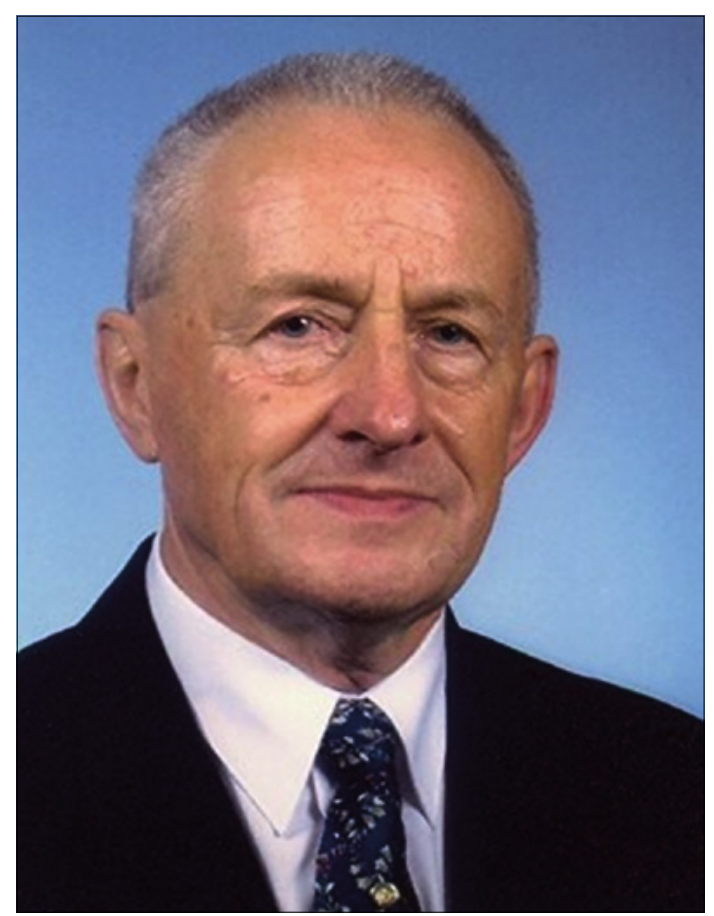

$\mathrm{W}$ roku 2017 jubileusz 80-lecia urodzin obchodzil profesor zwyczajny dr hab. Tadeusz W. Hermann, wieloletni kierownik Katedry i Zakładu Farmacji Fizycznej i Farmakokinetyki Uniwersytetu Medycznego im. Karola Marcinkowskiego w Poznaniu, były dziekan Wydziału Farmaceutycznego i prorektor ds. Nauki i Wspótpracy z Zagranicą. Profesor Tadeusz Hermann to przede wszystkim Wielkopolanin, który swoją konsekwentną pracą organiczną, w myśl biblijnej zasady „każdy wytrwały trud przynosi owoce”, zaszczepil wielu swoim wychowankom i studentom etos pracy u podstaw. Podczas 27 lat kierowania Katedrą Chemii Fizycznej, a później Katedrą i Zakładem Farmacji Fizycznej i Farmakokinetyki stworzył nowoczesny ośrodek dydaktyczno-naukowy o uznanej pozycji, zarówno w skali Polski, jak i świata. Wprowadzając nowy przedmiot farmakokinetyka do programu nauczania studentów farmacji, stał się pionierem nowoczesnej farmacji. Jego idee, ukierunkowane na współpracę farmaceuty z lekarzem i innymi członkami zespotu terapeutycznego, powoli stają się rzeczywistością w Polsce. Szanowny Jubilat jest wychowawcą i nauczycielem wielu pokoleń absolwentów farmacji i analityki medycznej. Zapisał się w pamięci wychowanków jako niestrudzony orędownik nowoczesnej farmacji i współpracy międzynarodowej na jej rzecz. Doskonale osobowość i zastugi profesora T. Hermanna oddal prof. dr Reinhard Neubert z Uniwersytetu Marcina Lutra w Halle, który w podsumowaniu swojej recenzji, w związku z nadaniem doktoratu honoris causa Gdańskiego Uniwersytetu Medycznego, napisat: Profesor Hermann jest znakomitym naukowcem, utalentowanym nauczycielem akademickim, wybitna światową osobistością w dziedzinie nauk farmaceutycznych.

Profesor Tadeusz Władysław Hermann urodził się 13 czerwca 1937 r. w Gnieźnie. Tam też uczęszczał do Państwowego Gimnazjum i Liceum Ogólnokształcącego im. Bolesława Chrobrego. W latach 1955-1960 studiował na Wydziale Farmaceutycznym Akademii Medycznej w Poznaniu, uzyskując tytuł zawodowy magistra farmacji z wyróżnieniem. Stopień doktora nauk farmaceutycznych został mu nadany 13 lutego 1969 r. przez Radę Wydziału Farmaceutycznego Akademii Medycznej w Poznaniu na podstawie dysertacji naukowej „Kinetyka procesu samoutleniania chlorowodorku papaweryny w roztworach wodnych". Kolejny stopień naukowy - doktora habilitowanego - uzyskał w 1977 r. na macierzystym wydziale, na podstawie wyników prac badawczych obejmujących problem trwałości leków. Tytuł rozprawy habilitacyjnej: „Modelowy program chemicznych badań trwałości leków na przykładzie allobarbitalu”. Tytuł naukowy profesora nauk farmaceutycznych zostal mu nadany przez Radę Państwa PRL w 1989 r. Profesorem zwyczajnym został w 1994 r. Godność doktora honoris causa Gdańskiego Uniwersytetu Medycznego została mu nadana przez tamtejszą społeczność akademicką w 2011 r.

Bezpośrednio po zakończeniu studiów rozpoczął karierę naukowo-dydaktyczną w Katedrze i Zakładzie Chemii Farmaceutycznej w charakterze asystenta. W kolejnych latach zajmowal stanowiska starszego asystenta, adiunkta (od 1969 r.), docenta 
(od 1979 r). W 1980 r. obją stanowisko kierownika Katedry i Zakładu Chemii Fizycznej, które piastowat do października 2007 r., przechodząc na zastużoną emeryturę. W tym czasie Katedra zyskała ugruntowaną pozycję naukową, jak i dydaktyczną. Profesor sprawowal też ważne stanowiska w administracji Uczelni. W latach 1984-1987 petnil funkcję prodziekana Oddziału Analityki Medycznej, a następnie został wybrany na dziekana Wydziatu Farmaceutycznego, którą to funkcję pełnit przez dwie kadencje, do 1993 r. W czasie kadencji dziekana Wydziału została utworzona szkoleniowa apteka akademicka. W kolejnych latach 1993-1999, przez dwie kadencje, sprawowat funkcję prorektora ds. Nauki i Współpracy z Zagranicą. Doprowadził do podpisania umowy o współpracy z Wydziałem Farmaceutycznym Wolnego Uniwersytetu w Berlinie. Jest twórcą Polsko-Niemieckiego Sympozjum Wydziałów Farmaceutycznych, którego niedawno odbyła się 9. edycja. Sympozja te poprzednio dotyczyły tylko wydziałów farmaceutycznych w Poznaniu i Halle.

Profesor Tadeusz Hermann doskonalił swój warsztat naukowy w ośrodkach zagranicznych pod kierunkiem uznanych autorytetów naukowych: prof. dr. Edwarda R. Garretta w College of Pharmacy, University of Florida, Gainesville (1971-1972) i prof. dr. J.V. Swintosky'ego oraz prof. dr. H.B. Kostenbaudera z College of Pharmacy, University of Kentucky w Lexington (1981). Podczas pierwszego pobytu dr. T. Hermann zdobywał umiejętności w zakresie badań trwałości i kinetyki procesów degradacji leków, które z powodzeniem przeniósł na grunt macierzystej uczelni. Badania te kontynuowane są po dzień dzisiejszy. Kolejne doświadczenie, dotyczące tym razem analizy leków i metabolitów w płynach ustrojowych z przeznaczeniem do badań farmakokinetycznych oraz w ocenie biodostępności leków, prof. T. Hermann zdobył w College of Pharmacy, University of Kentucky. Doświadczenie to zaowocowało podjęciem badań w kierunku farmakokinetyki klinicznej takich leków, jak: azatiopryna, 6-markaptopuryna czy metotreksat. Badania były prowadzone we współpracy z jednostkami klinicznymi w Poznaniu i byly początkiem wspólpracy farmaceutów z lekarzami w zakresie terapeutycznego monitorowania leków. Staraniem profesora Tadeusza Hermanna wprowadzono, po raz pierwszy w Polsce, przedmiot farmakokinetyka do programu studiów farmaceutycznych. W latach 1991 i 1994 przebywat na stypendium DAAD w Uniwersytecie Christiana Albrechta w Kilonii pod kierownictwem prof. B.W. Müllera.

Zainteresowania badawcze Profesora podczas całej kariery naukowej koncentrowały się głównie na badaniach kinetyki i mechanizmu reakcji chemicznych powodujących niestabilność leków, farmakokinetyki, dostępności biologicznej oraz terapeutycznego monitorowaniu leków. Znaczące miejsce, zwłaszcza w ostatnich latach, zajmowata tematyka badawcza dotycząca rozwiazywania struktury nowych związków chemicznych o działaniu przeciwnowotworowym we współpracy z dr. Urlichem Girreserem z Wydziału Farmaceutycznego w Kilonii. Wyniki badań naukowych prof. Hermann opublikowat w ponad 106 oryginalnych doświadczalnych pracach naukowych w czasopismach o cyrkulacji międzynarodowej, takich jak: Arch. Pharm. Pharm. Med. Chem., J. Pharm. Sci., Med. Sci. Monit., Int. J. Pharm. Był też recenzentem publikacji w krajowych, jak i zagranicznych naukowych czasopismach specjalistycznych.

Profesor Tadeusz Hermann za swoją działalność dydaktyczną zyskał uznanie ze strony polskich studentów farmacji, jak i studentów programu anglojęzycznej farmacji. Pod jego kierunkiem zostały przygotowane skrypty dydaktyczne z chemii fizycznej oraz farmakokinetyki. Pod redakcją prof. T.W. Hermanna ukazały się podręczniki akademickie z farmacji fizycznej (1999 r.) oraz chemii fizycznej (2007 r.). Ponadto jest autorem podręcznika „Farmakokinetyka. Teoria i praktyka” (2002 r.). Łącznie profesor T. Hermann jest autorem 22 podręczników czy też rozdziałów w podręcznikach oraz skryptów akademickich. Swoje osiągnięcia naukowe prezentowat na ponad 80 konferencjach, zjazdach krajowych i zagranicznych. Opublikowane prace referatowe obejmują ponad 30 pozycji. Ponadto jest autorem 32 nieopublikowanych prac wykonanych na rzecz przemysłu farmaceutycznego w latach 1968-2001.

Dorobek prof. T. Hermanna w zakresie ksztalcenia młodych kadr naukowych obejmuje promotorstwo 7 doktoratów oraz dużej liczby prac magisterskich. Ponadto jest patronem 4 habilitacji oraz promotorem doktoratu honoris causa prof. R. Neuberta (2004 r.), prorektora Uniwersytetu M.L. oraz dziekana Wydziału Farmaceutycznego w Halle.

Działalność organizacyjna profesora T. Hermanna obejmuje udzial w komisjach, radach i innych organizacjach naukowych: Komitet Chemii Analitycznej PAN: Komisja Analizy Leku - przewodniczący (1980-1995), członek (1980-2007); Komitet Nauk o Leku PAN - członek (1984-1997); Komitet Terapii i Nauk o Leku PAN - członek (2001-2006), zastępca przewodniczącego (2007 r.); PTPN, Wydział IV Lekarski - czlonek (od 1990 r.); Komisja Farmaceutyczna - czlonek (od 1988 r.); PAN, Oddział w Poznaniu, Komisja Nauk Chemicznych - członek (1993-2007); Komisja Farmakopei Polskiej, Zespół Nauk Fizykochemicznych - przewodniczący (1997-2003); Polskie Tow. Farm., Oddz. 


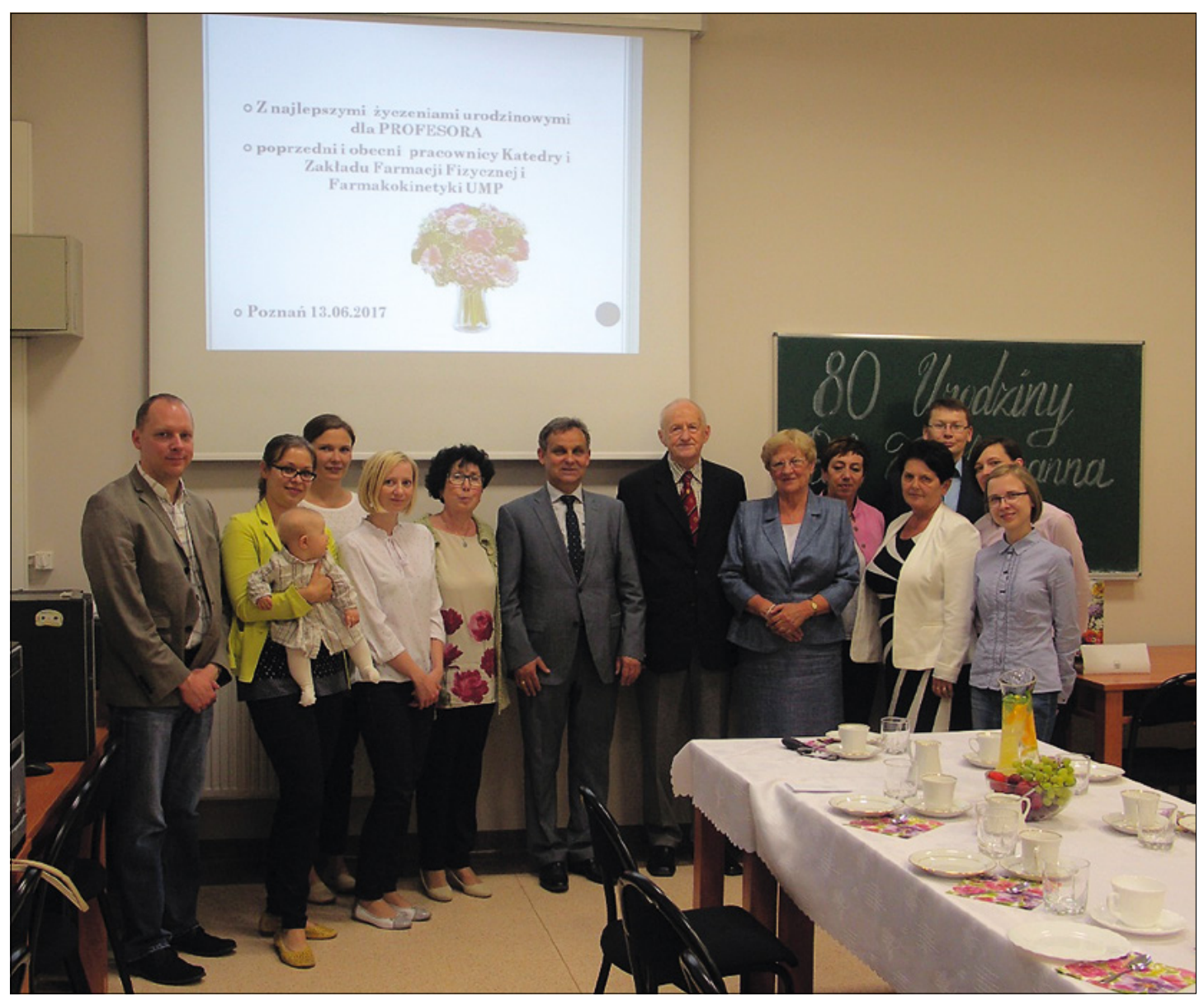

w Poznaniu - wiceprzewodniczący (lata 80. jedna kadencja, u boku prof. Z. Kowalewskiego), Sekcja Analityczna - przewodniczący (1974-1980); European Federation for Pharmaceutical Sciences (EUFEPS) - członek (1998-2000). Był też członkiem Centralnej Komisji ds. Stopni i Tytułów Naukowych (2000-2006).

Za osiągnięcia w działalności naukowej, dydaktycznej i organizacyjnej profesor T. Hermann został uhonorowany licznymi odznaczeniami m.in. Krzyżem Oficerskim Orderu Odrodzenia Polski - 1999 r., Krzyżem Kawalerskim Orderu Odrodzenia Polski - 1988 r., Złotym Krzyżem Zasługi - 1981 r., Medalem Komisji Edukacji Narodowej - 2005 r., Medalem Pamiątkowym za zasługi dla polskiej farmacji - 2011 r., Odznaką Honorową Za zastugi $w$ rozwoju województwa poznańskiego. Posiada studenckie odznaczenie Sowa z wieńcem laurowym oraz złotą odznakę Akademickiego Związku Sportowego. Jest laureatem m.in. Nagrody I stopnia Ministra Zdrowia i Opieki Społecznej za szczególne osiągniecia dydaktyczne w roku akademickim 1983/84 oraz za podręcznik pt.: „Farmacja fizyczna. Podręcznik dla studentów farmacji i analityki medycznej” (2000 r.), a także licznych nagród rektorskich m.in. im. W. Biegańskiego za wybitne wieloletnie osiągnięcia dydaktyczne i wychowawcze.

Prof. dr hab. Tadeusz Hermann, mimo przejścia na emeryturę, jest nadal aktywny naukowo. Publikuje prace o charakterze naukowym, jak i dydaktycznym w Acta Poloniae Pharmaceutica - Drug Research, Farmacja Polska czy The Open Acccess Journal of Pharmaceutical Research. Od 1997 r. organizował zajęcia, a także osobiście prowadził (do 2014 r.) wykłady i seminaria z physical chemistry dla studentów 2. roku programu anglojęzycznego. Żywo zainteresowany jest działalnością i rozwojem macierzystej Katedry Farmacji Fizycznej i Farmakokinetyki. Uczestniczy w spotkaniach naukowych, jak i okolicznościowych organizowanych w Katedrze, podczas których chętnie dzieli się swoim cennym doświadczeniem zarówno naukowym jak i życiowym.

Otrzymano: 2017.12.27 - Zaakceptowano: 2018.01.20 